\title{
Prolonged Febrile Syndrome in a Patient from the Jungle Region of Colombia, About A Case
}

\author{
Jhon Alejandro Rico Gallego*, Fabián Felipe Saldarriaga Arias and Liseth Lorena Quintero Herrera \\ General physician, emergency service, Colombia
}

*Corresponding author: Jhon Alejandro Rico Gallego, General physician, emergency service, Hospital San Vicente de Paúl, Santa

Rosa de Cabal, Risaralda, Colombia

\begin{tabular}{ll}
\hline ARTICLE INFO & ABSTRACT \\
$\begin{array}{l}\text { Received: 慧 February 08, } 2019 \\
\text { Published: }\end{array}$ & $\begin{array}{l}\text { Citation: Jhon Alejandro Rico G, Fabián Felipe Saldarriaga A, Liseth Lorena Quintero H. } \\
\text { Prolonged Febrile Syndrome in a Patient from the Jungle Region of Colombia, About A } \\
\text { Case. Biomed J Sci \& Tech Res 14(5)-2019. BJSTR. MS.ID.002606. }\end{array}$ \\
\hline
\end{tabular}

\section{Introduction}

The prolonged febrile syndrome is defined as any clinical presentation with body temperature $>38.3^{\circ} \mathrm{C}$ in adult patients, of more than 10 days duration, without obvious infectious focus to the detailed physical examination and without definite etiology after paraclinical studies [1] developed in the institution where the patient is. Below we present the case of a tourist of French nationality who 15 days before the consultation to our health center visited jungle area of the department of Chocó - Colombia and was in contact with aboriginal indigenous population of that area.

\section{Case Report}

A 51-year-old male patient of French nationality, with no medical history of importance, is presented to the emergency department of the San Vicente de Paúl Hospital (Santa Rosa de Cabal, Risaralda, Colombia), who reports clinical symptoms of 15 days of evolution consisting of not quantified febrile peaks, predominantly nocturnal, associated with chills, diaphoresis, myalgias, arthralgias, occasional abdominal pain, as a colic, diffuse and with mild intensity, asthenia, adynamia and deterioration of functional class to reach to the prostration, denied use of intravenous drugs, denied other associated symptoms. When inquiring about the reason for his stay in the country refers to tourism and says that 15 days before the consultation was lodged for 2 days in an indigenous tribe (EmberaChamí) in the jungle area of the department of Chocó (endemic region for infectious-contagious diseases transmitted by vectors), initially manifested an intervention at another health care center where they carry out a blood count exam that was brought to our practice but was referred as "had low platelets" for such a reason they made a diagnostic impression of dengue (without serological confirmation) and sent him home with paracetamol and oral rehydration salts.

On admission to our service we found patient in regular general health conditions, vital signs: BP: 90/60 mmHg, HR: 125 lpm, BR: $16 \mathrm{rpm}, \mathrm{T}: 38.6^{\circ} \mathrm{C}$, Sato2: $97 \%$, conscious, alert , oriented in 3 spheres, with clinical signs of mild dehydration, hypotensive, with SIRS given by fever and tachycardia, negative Q-sofa for sepsis ( 1 point for systolic blood pressure $<100 \mathrm{mmHg}$ ), physical examination showed generalized skin and mucous membranes paleness, without evident infectious focus, symptomatic medical management was administered (intravenous fluids Hartmann and paracetamol) and within the complementary studies (blood count, creatinine, bilirubins, uroanalysis), thick blood was requested given the epidemiological link described (Table 1). With the results of the studies carried out, it was concluded as a Malaria diagnosis by Plasmodium Vivax, first line medical treatment was initiated according to Colombian guidelines of the infectology association (Cloroquine + Primaquine) and medical support management was given too, with satisfactory clinical evolution, normalization of the vital variables and in the control paraclinics (except in hemoglobin as expected in these cases), finally 4 days later hospital discharge was done with indication of continuing Primaquine until completing 14 doses. 
Table 1: Results of paraclinical studies performed at admission and during the hospital stay.

\begin{tabular}{|c|c|c|c|}
\hline Paraclinics & First Medical Contact & 48 Hours Later & 96 Hours Later \\
\hline Blood Count & & & \\
\hline Leukocytes (10 exp 9 Cells/L). & 6,31 . & 4,94 . & 4,58 \\
\hline Neutrophils (\%). & 85,5 & 60,3 & 56,3 \\
\hline Lymphocytes (\%). & 8,5 . & 37,3 . & 38. \\
\hline $\mathrm{Hb}(\mathrm{gr} / \mathrm{dL})$ & 10,5 & 10,4 & $9,3$. \\
\hline $\mathrm{MCV}(\mathrm{fL})$ & 78. & 78. & 77. \\
\hline $\mathrm{MCH}(\mathrm{Pg})$. & 28,3 . & 29. & 28,7 . \\
\hline Hematocrit (\%). & 29. & 28. & 25,1 \\
\hline Platelets (10 exp 9 Cells/L). & 61. & 65. & 105. \\
\hline Creatinine (mg/dL) & 1,68 & 1,13 & \\
\hline Uroanalysis (campo visual). & $\begin{array}{c}\text { Color: amber, appearance: cloudy, density: } 1.015, \mathrm{Ph}: 5 \text {, bacteria: }++ \text {, } \\
\text { granular cylinders: }++.\end{array}$ & & \\
\hline Bilirubins (mg/dL). & & & \\
\hline Total & 1,4 . & 0,8 & \\
\hline Direct & 0,87 . & 0,46 . & \\
\hline Indirect & 0,53 . & 0,34 . & \\
\hline Thick droplet (\# of parasites / $\mu \mathrm{L}$ ). & $\begin{array}{l}\text { P. Vivax: } 11.629 . \\
\text { P. Falciparum: } 0 .\end{array}$ & & $\begin{array}{c}\text { P. Vivax: } 0 . \\
\text { P. Falciparum: } 0 .\end{array}$ \\
\hline
\end{tabular}

\section{Discussion}

The prolonged febrile syndrome is defined as any clinical presentation with body temperature $>38.3^{\circ} \mathrm{C}$ in adult patients, of more than 10 days duration, without evident infectious focus to the detailed physical examination and without defined etiology after paraclinical studies [1] developed in the institution where the patient is, within the spectrum of diagnostic possibilities there are infectious causes (parasites, viruses, bacteria, fungi), neoplasms, connective tissue diseases, miscellaneous or cryptogenic (not diagnosed) [2,3]. An adequate questioning and a thorough physical examination should guide the clinician to which of this group of diseases direct their efforts in order to request the pertinent studies, in our case, taking into account that the patient's provenance (Chocó) which is an endemic area for infectious-contagious diseases transmitted by vectors (Dengue, Zika, Chikungunya, Leptospirosis and Malaria, whose annual parasitic index-IPA is > 10 cases / 1000 inhabitants) [4], the studies described in figure 1 were requested, among them, the thick drop which resulted positive for P. Vivax and based on the therapeutic guidelines described by the Ministry of National Health of Colombia, first line treatment was established with Cloroquine + Primaquine [5], evidencing significant clinical and paraclinical improvement, achieving normalization of vital variables and give discharge of the institution in optimal health conditions.

\section{Conclusion}

To conclude, it is important to highlight the adequate interrogation as the greatest diagnostic tool that allows us, as in this case, to properly guide the patient, to make a syndromic diagnosis and request the relevant studies to clarify their symptoms.

\section{References}

1. Delor R, Fridman V (2016) Clinical management of adults with prolonged fever. Rev Med La Paz 22(2).

2. Palafox G, Martín JP (2011) Fever of unknown origin. The challenge of internal medicine. Med Int Mex 27(6): 573-585.

3. Navea O, Aguilera P, Velasco M-I, et al. (2011) Evaluation of the adult patient with fever without evident clinical focus in the emergency unit. Rev Chil Med Intensive 26 (3): 181-188.

4. (2018) Epidemiological behavior of Malaria in Colombia during the year 2017. National Institute of Health, Version 1-19.

5. Padilla JC, Montoya R (2011) Clinical care guide for Malaria. Colombian Association of Infectious Diseases. Infectio 15(4): 302-323. 


\section{ISSN: 2574-1241}

DOI: 10.26717.BJSTR.2019.14.002606

Jhon Alejandro Rico Gallego. Biomed J Sci \& Tech Res

(C) (i) This work is licensed under Creative

Submission Link: https://biomedres.us/submit-manuscript.php

$\begin{array}{ll}\text { BIOMEDICAL } & \text { Assets of Publishing with us } \\ \text { RESEARCHES } & \text { - Global archiving of articles } \\ \text { - Immediate, unrestricted online access }\end{array}$

